\title{
Antagonistic Activity and Production of Antifungal Compound(s) from Selected Trichoderma spp.
}

\section{Omar Mu'ayad Al-Obaidy Maha Akram Al-Rijabo \\ Department of Biology / College of Science \\ Mosul University/Iraq}

Received

$.7 / 0 \leqslant / 201$.
Accepted

09 / 05 / 2010

\section{الخلالصة}

مق لستخدلم عزلتان من جنس الفطر T.harzianum و T.tiride) Trichoderma

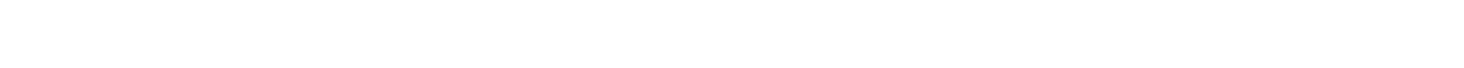

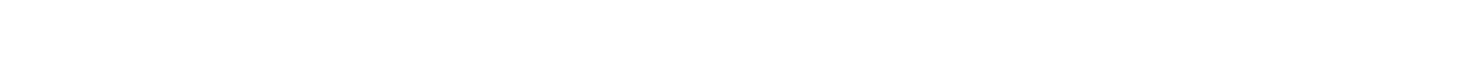

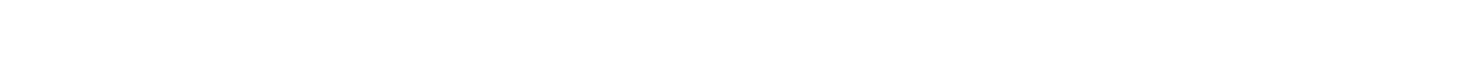

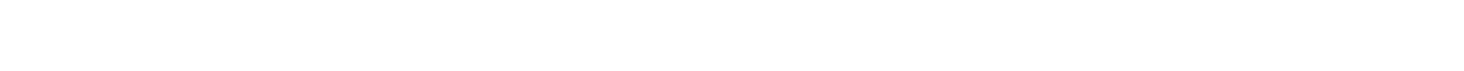

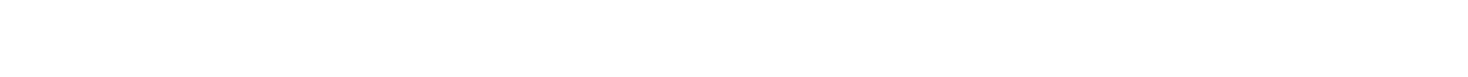

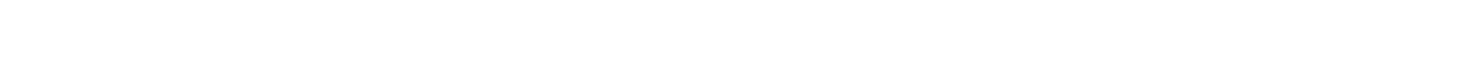
الفعالية التنبطية ضد النطريك.

\section{ABSTRACT}

Two Trichoderma spp. (T.harzianum and T.viride) which are well known for their use as biocontrol agents were used in this study and tested for their antagonistic activity against several plant pathogenic (and even human pathogenic) fungi, also the activity was tested against selected Gram positive and Gram negative bacteria. The proper conditions for the production of the antifungal compound were determined, and after the production and extraction of the antifungal compounds from the two Trichoderma spp., an attempt to partially characterize the nature of the antifungal compound(s) was done using several chemical analysis methods, and the results showed that the inhibition was due to the production of antifungal compounds that had many similar characteristics for both T.harzianum and $T$. viride but with a difference in their antifungal actions. 


\section{Introduction}

At present, around 30\% of all plant species have been destroyed by plant pathogens. Pesticides and organic compounds are widely used to control plant pathogens in many countries. However, the degradation of such compounds is very difficult and the concentration and/or accumulation of them in food chains are leading to higher toxicity levels in animals (1). Trichoderma species have been investigated for over 80 years. They have been used recently as biological control agents and their isolates have become commercially available of late. This development is largely the result of a change in public attitude towards the use of chemical pesticides and fumigates such as methyl bromide (2 and 3 ). In this respect, Trichoderma spp. have been studied as biological control agents against soil-borne plant pathogenic fungi $(4,5,6)$. Results from different studies showed that several strains of Trichoderma had a significant reducing effect on plant diseases caused by pathogens such as Rhizoctonia solani, Sclerotium rolfsii, Phythium aphanidermatium, Fusarium oxysporum, F. culmorum and Gaeumannomyces graminis var. tritici under greenhouse and field conditions (7-11). Knowledge concerning the behaviour of these fungi as antagonists is essential for their effective use because they can act against pathogens in several ways (12). Isolates of Trichoderma harzianum can produce lytic enzymes(13) and antifungal antibiotics $(14,15,16)$ and they can also be competitors of fungal pathogens (10), and promote plant growth (9). Also isolates of Trichoderma viride are well known to produce antifungal metabolites like acetaldehyde. It was reported that the production of metabolites from different Trichoderma strains depends on ecological factors, and so the strains show varying effects on pathogens (17and 18). Some of these metabolites have been isolated from sporulating or mycelial cultures but subcultivation decreased the production of the peptide antibiotics produced by Trichoderma isolates (19and 20).

The most frequently suggested mechanisms of biocontrol by Trichoderma include mycoparasitism, antibiosis, competition for nutrients, or all of the above. Trichoderma can inhibit the pathogen by means of antibiotics $(21,22)$ or cell wall-degrading enzymes (CWDEs) (23) such as chitinases (24,25), glucanases (26), proteases (27), mannanases, and other hydrolases (28). The relative importance of these two mechanisms in the antagonistic process depends on specific pathogen host interactions $(29,30)$.

The aim of this study was to test and compare the biological activity of Trichoderma harzianum and Trichoderma viride against several plant (and even human pathogenic) fungi (also to test the antibacterial activity) and to produce and extract the active compound(s) from each fungus, and also to partially identify the nature of these compound(s).

\section{Materials and Methods}

\section{Fungal strains :}

a) The biocontrol Trichoderma harzianum and Trichoderma viride that were used for the antagonistic activity were taken from the Plant Protection Department/College of Agriculture/Mosul University. 
b) The plant pathogenic fungi Penicillium nalgiovense, Fusarium graminearum, Alternaria alternata, were taken from Biology Department/ College of Science/ Mosul University.

c) The human pathogenic fungi Aspergillus niger, and Aspergillus flavus were taken from Biology Department/ College of Science/ Mosul University.

\section{Antifungal bioassay test ( Dual culture tests):}

Interactions between antagonistic fungi and pathogenic fungi were determined by the method described by Kucuk and Kivanc (35). Mycelial disks ( $7 \mathrm{~mm}$ in diameter) of pathogenic fungi were placed on one edge of a petri dish containg potato dextrose agar (PDA) or Sabroud agar in the case of human pathogenic fungi, while mycelia disks of Trichoderma spp. (T.harzianum and T.viride) were placed on the opposite side of the plate. After the desired incubation time (about 7 days), at $28^{\circ} \mathrm{C}$, the overgrowth of colonies of the test fungi by the antagonist was determined.

\section{Production and extraction of the antifungal compound(s) from Trichoderma spp.}

A water-soluble component(s) was extracted with butanol from the culture filtrates of T. viride and T.harzianum grown for 14 days. Pooled culture filtrate $(50 \mathrm{ml})$ was clarified through Whatman no. 3 filter paper and extracted 2 times with $50 \mathrm{ml}$ of butanol. The butanol extract $(100 \mathrm{ml})$ were pooled dried in a water bath (22 liters Genlab limited) at $60^{\circ} \mathrm{C}$ for 7 to $8 \mathrm{~h}$ each day for three successive days. To determine the biological activity of the butanol extracts, the residues were dissolved each in $10 \mathrm{ml}$ of sterile distilled water and from these solutions, $1 \mathrm{ml}$ portion of each of the Trichoderma species extracts $(100 \%)$ and the serial dilutions $(70 \%$, $50 \%, 30 \%$ and $10 \%$ if needed) was pipetted into different wells $(8 \mathrm{~mm}$ diameter) borne on the surface of solidified PDA plates $(9 \mathrm{~cm}$ diameter $)$ previously prepared to allow excess water evaporate (pH6) (31).

\section{Partial characterization of the produced antifungal compounds:}

Several tests were done to partially characterize the nature of the active crude extract such as heat treatment, nature of the Compound(s), solubility of the compound(s), FTIR analysis and others.

\section{Results and Discussion:}

\section{Antifungal bioassay test:}

The two Trichoderma spp. (Trichoderma harzianum and Trichoderma viride) were subjected to the bioassay test against different phytopathogenic (and even human pathogenic) fungi using the dual culture technique and the results were as follow: 
When the isolate Trichoderma harzianum grown with the fungus Alternaria alternata, the fungus T.harzianum completely cover the plate (over growth upon the fungus Alternaria alternata) (Figure 1), which mean that the fungus T.harzianum degrade or hydrolyse the fungus A.alternata and the same thing happened when T.harzianum grown with Fusarium graminearum and Penicillium nalgiovense and this may be due to the production of hydrolytic enzymes or compounds that completely hydrolyse the other fungi, but it has no effect on the fungus Aspergillus niger and Aspergillus flavus, while the fungus T. viride inhibits the growth (mycelial growth) of A. alternata in a ratio of $94.2 \%$ and of $F$. graminearum in a ratio of $76.5 \%$ and have no effect on the growth of $P$. nalgiovense, Aspergillus niger, and Aspergillus flavus.

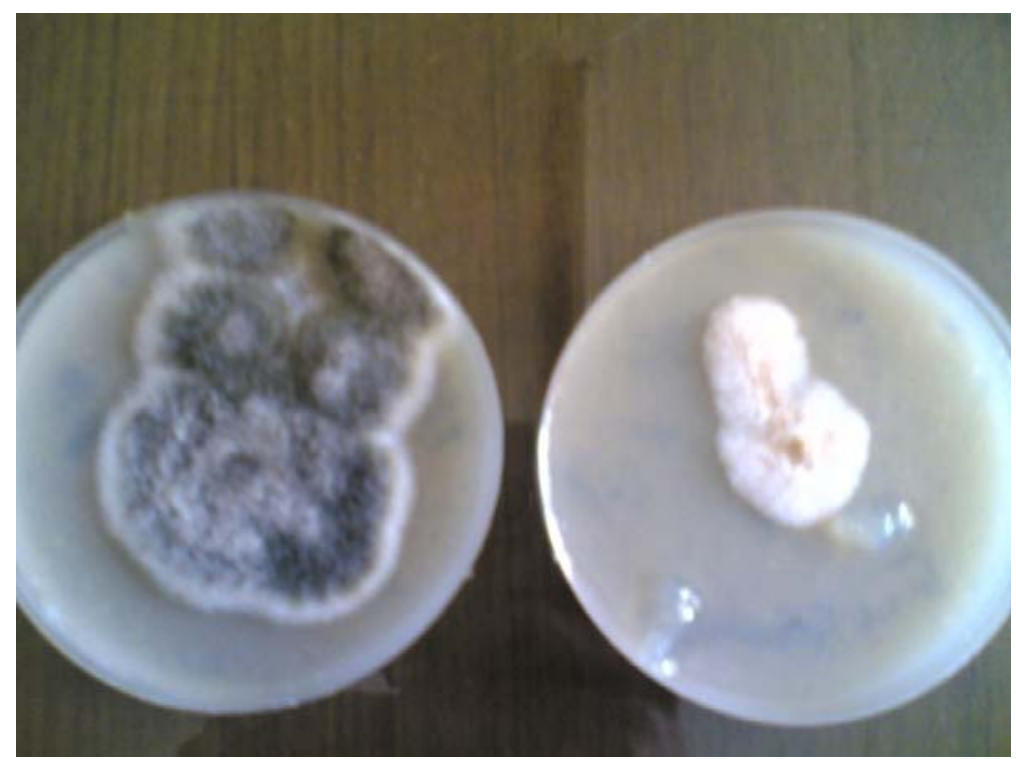

A

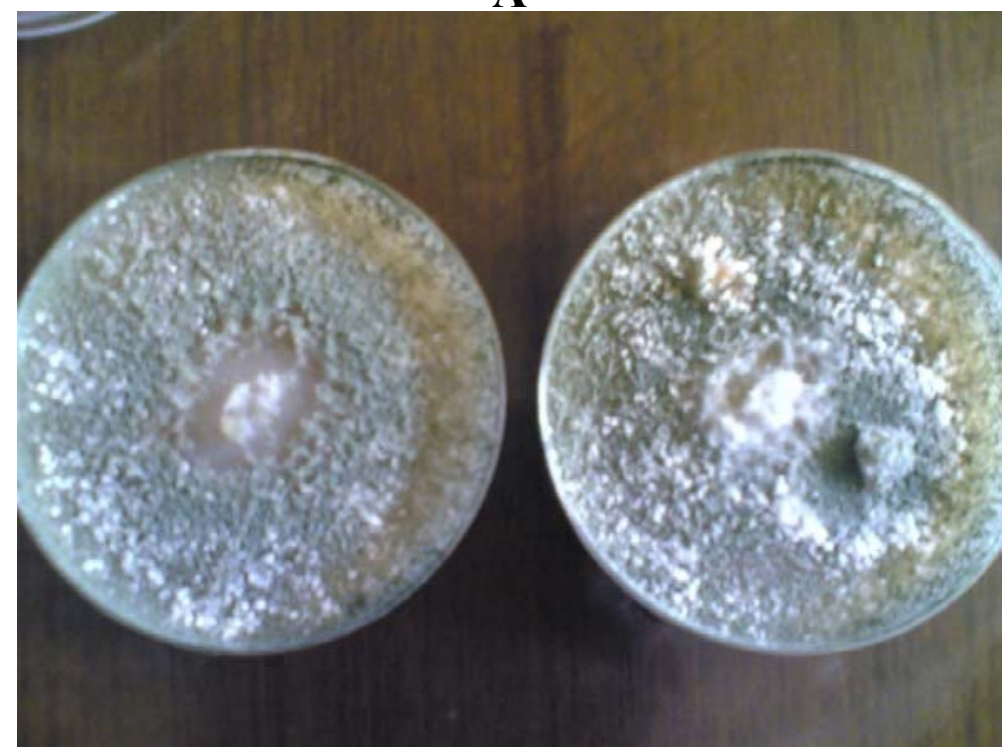

B

Figure (1): A: The growth of the fungus Alternaria alternata (left) and growth of the fungus Fusarium graminearum(right) \{Controls\}. B:The growth of the fungus Trichoderma harzianum (left) and the overgrowth of the fungus T.harzianum over the fungi A.alternata, and F.graminearum. 
From the above it appears that the isolate T.harzianum is more efficient against the tested fungi than $T$. viride and that is in agreement with (3).

On the other hand, and from previous studies (data not shown), it is well known that some kinds of Gram Positive bacteria such as Bacillus subtilis and Bacillus cereus(32) and some kinds of Gram Negative bacteria such as Pseudomonas spp. (P.aeruginosa and P.flourescens) (33) have an antifungal activities against a variety of fungi, and when we test these bacteria (Bacillus subtilis and Pseudomonas aeruginosa) for their antifungal activity against $T$. harzianum and T.viride, they showed no effect on these fungi.

It is well known that some kinds of T.harzianum produce anovel tetramic acid with a remarkable activity against Gram-positive bacteria especially Staphylococcus aureus and Bacillus subtilis (34), but when our culture filtrates of T.harzianum and T.viride were tested against the Gram-positive bacteria Bacillus subtilis and Staphylococcus aureus, they showed no activity, also they showed no activity against the Gramnegative bacteria Pseudomonas aeruoginosa and E.coli.

\section{Extraction and partial characterization of the antifungal compound(s) of T.harzianum and T. viride :}

As mentioned by the method described by (33), the crude extract of each T.harzianum and T.viride (which was dissolved in butanol) was taken for serial dilutions and another extracts were taken and evaporated from butanol for further studies.

It was found that the optimum conditions for the production of antifugal compound(s) from T.harzianum and T.viride was growing the fungi at $28^{\circ} \mathrm{C}$ for two weeks on potato dextrose agar (for antifungal assay) or potato dextrose broth for production and extraction of the antifungal compounds, and that was in agreement with (33).

The culture filtrate (not diluted) of T.harzianum showed an inhibition zone of $1.5 \mathrm{~cm}$ on Alternaria alternata and of $1 \mathrm{~cm}$ on Fusarium graminearum, while the culture filtrate of $T$. viride showed inhibition zone of $1 \mathrm{~cm}$ on A.alternata and of $0.7 \mathrm{~cm}$ on Fusarium graminearum (Figure 2), but the culture filtrate of both T.harzianum and T.viride showed no effect against the fungi Aspergillus niger, Aspergillus flavus, and Penecillum nalgiovense . 


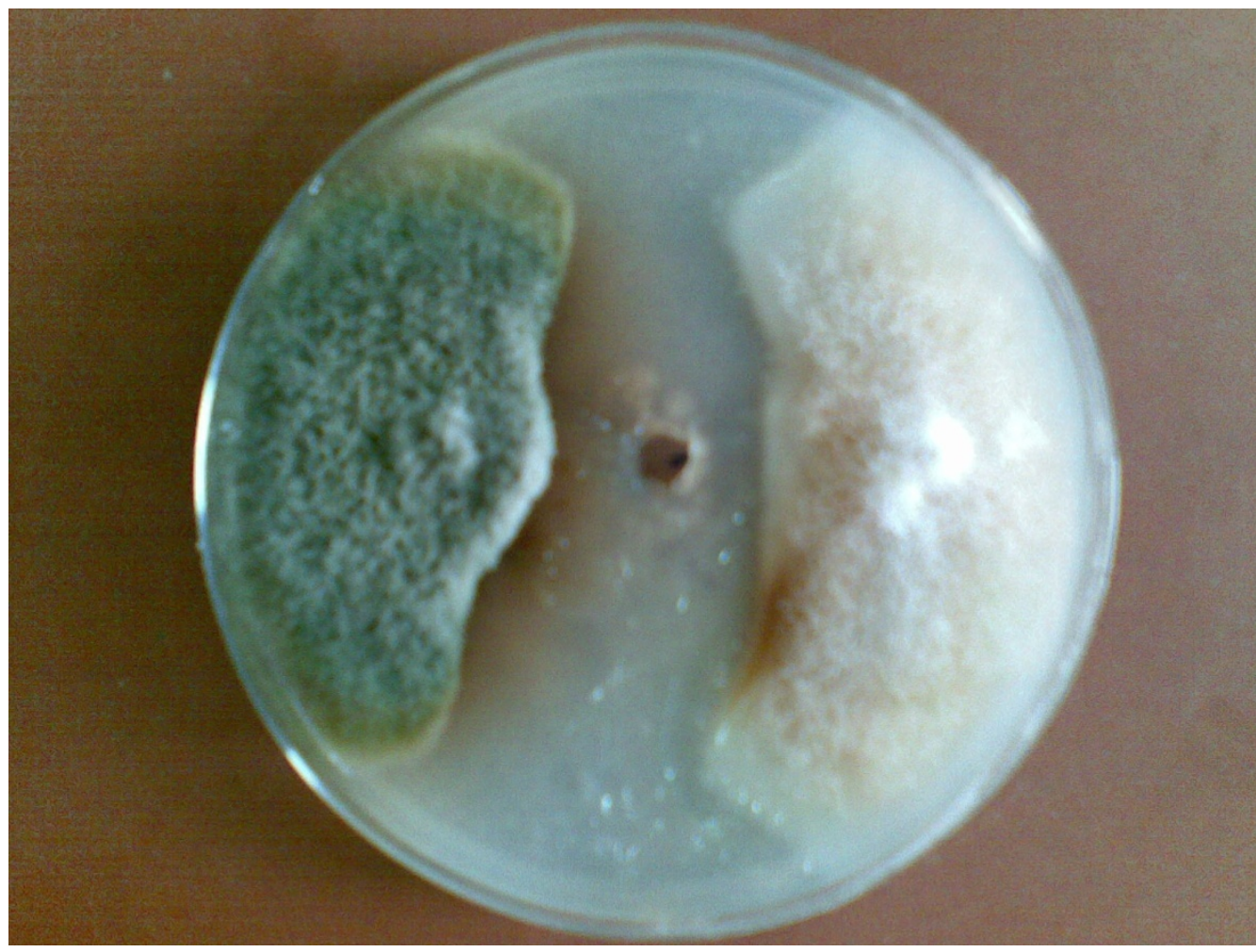

Figure (2): The effect of the culture filtrate of the fungus T.harzianum on the fungi A.alternata (left) and F.graminearum (right).

When the culture filtrate of both T.harzianum and T.viride was subjected to heat treatment $\left(100^{\circ} \mathrm{C}\right.$ for 10 minutes), there was no effect on the activity of the compounds because they showed approximately the same results of the untreated compounds on A.alternata and F.graminearum.

Also, the culture filtrates showed solubility in organic compounds such as butanol, ethanol, dimethyl sulfoxide (DMSO) and others in addition to water.

When an FTIR analysis was done to the culture filtrate of T.harzianum and T.viride (Figure 3 and 4), they showed approximately the same absorbtion bands of the active compounds with a little difference in the absorbtion band of 1721.98 in the compound of T.viride.

Also the FTIR results showed the presence of an aromatic ring in both compounds of T.harzianum and T.viride. 


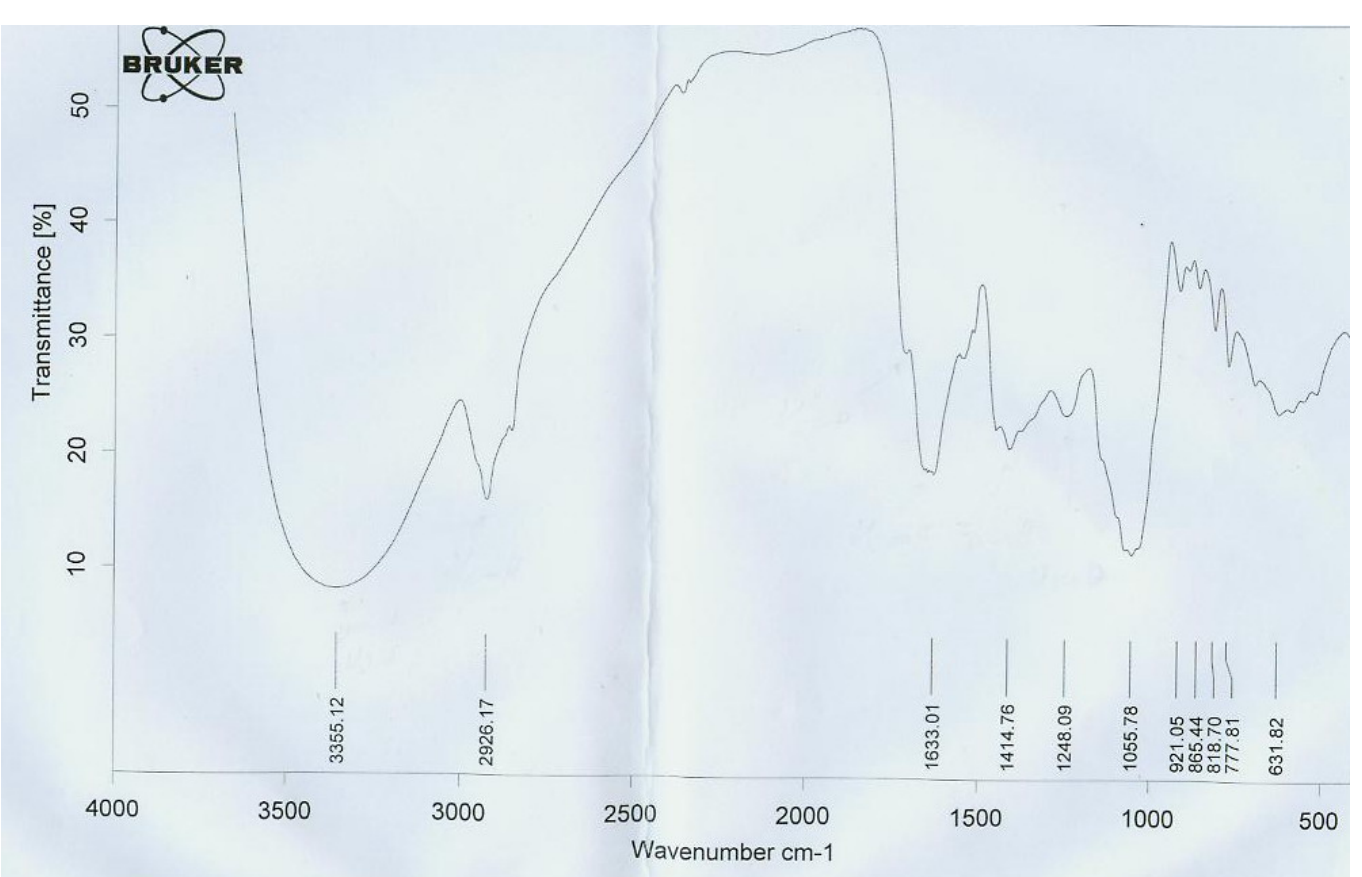

Figure (3): The FTIR analysis of the active compound(s) of the fungus Trichoderma harzianum.

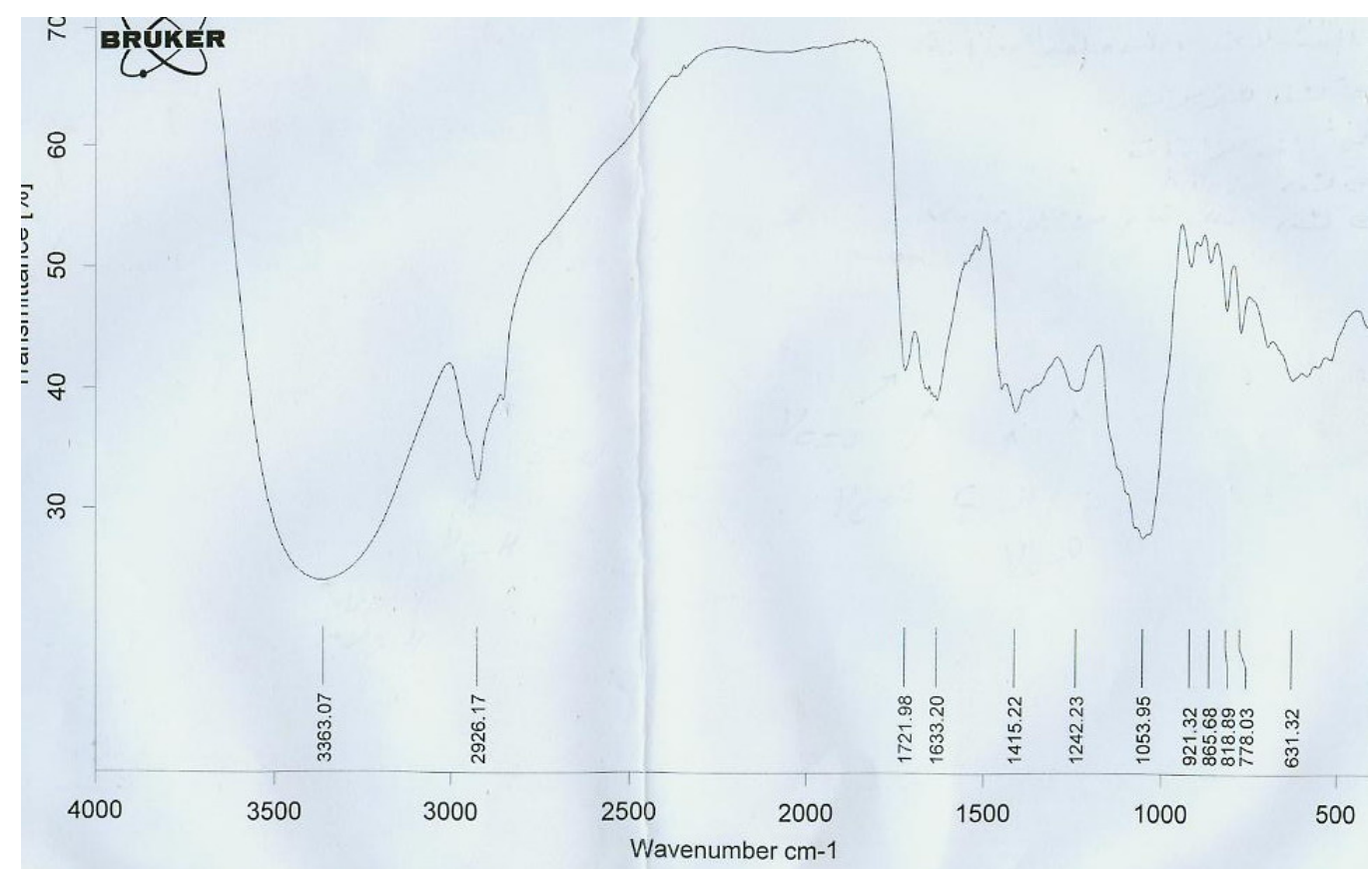

Figure (4): The FTIR analysis of the active compound(s) of the fungus Trichoderma viride.

From all above it seems or we can conclude that the extracted antifungal compound(s) of both T.harzianum and T.viride had many similar characteristics with a little difference as demonstrated in the FTIR analysis that is recommended to do full characterizations and analysis of these compounds such as mass spectrophotometry, HPLC, and NMR etc., but it is most likely that they are from the same group of antibiotics that 
have an aromatic ring, but with the great difference in their action in which the fungus T.harzianum had much more antifungal activities than the fungus T.viride as seen in our research and also because of the greater inhibition zone of the culture filtrate of T.harzianum than the culture filtrate of T.viride.

\section{References}

1) Lynch J. M. Fungi as Atagonists. In: New Directions in Biological Control: Alternatives for Suppressing Agricultural Pests and Diseases, Liss, New York, pp. 243-253 (1990).

2) Elad Y., Chet I., and Katan Y. Trichoderma harzianum a biocontrol agent effective against Sclerotium rolfsii and Rhizoctonia solani. Phytopathology. 70: 119-121 (1980).

3) Basim H., Ozturk SB., and Yegen O. Effificacy of a biological fungicide (Planter Box (Trichoderma harzianum Rifai T-22)) against seedling root rot pathogens (Rhizoctonia solani, Fusarium sp.) of cotton. GAP-Environmental Symposium. sanliurfa, Turkey. p.137-144 (1999).

4) Henis Y. Biological control. In "Current Perspectives in Microbial Ecology", eds. Klug, M. J.; Reddy C. A., American Society of Microbiology, Washington pp. 353-361 (1984).

5) Chet I., and Baker R. Induction of suppressiveness to $R$. solani in soil. Phytopathology. 70: 994-998 (1980).

6) Chet I., and Inbar J. Biological Control of Fungal Pathogens. Applied Biochemistry and Biotechnology. 48: 37-43 (1994).

7) Bell D. K., Wells H. D., and Markham C. R. In vitro antagonism of Trichoderma spp. against six fungal pathogens. Phytopathology 72:379-382 (1982).

8) Sivan A., and Chet I. Integrated Control of Media on Growth and Interactions between a range of Soilborne Glasshouse Pathogens and Antagonistic Fungi. Phytopathology 10: 127-142 (1993).

9) Inbar J., Abramsky M., and Cohen D. Plant Growth Enhancement and Disease Control by Trichoderma harzianum in Vegetable Seedlings Grown under Commercial Conditions. European Journal of Plant Pathology 100: 337-346 (1994).

10) Whipps JW. Effect of Media on Growth and Interactions between a Range of Soil-borne Glasshouse Pathogens and Antagonistic Fungi. New Phytopathology 107: 127-142 (1987).

11) Chet I., and Baker R. Isolation and biocontrol potential of Trichoderma hamatum from soil naturally suppressive to $R$. solani. Phytopathology 71: 286-290 (1981). 
12) Chet I. Trichoderma Application, Mode of Action and Potential as a Biocontrol Agent of Soil-borne Plant Pathogenic Fungi. In: Innovative Approaches to Plant Disease Control, ed. Chet I., Wiley, New York, pp. 137-160 (1987).

13) Haran S., Schickler H., and Chet I. Molecular Mechanisms of Lytic Enzymes Involved in the Biocontrol Activity of Trichoderma harzianum. Microbiology 142: 2321-2331 (1996).

14) Dennis C., and Webster J. Antagonistic Properties of Species Groups of Trichoderma. Production of non-volatile antibiotics. Trans BrMycol Soc 57: 25-39 (1971).

15) Brewer D., Mason F. G., and Taylor A. The Production of Alamethicins by Trichoderma spp. Candian Journal of Microbiology 33: 619-625(1987).

16) Almassi F., Ghisalberti E. L., and Narbey M. J. New Antibiotics from Strains of Trichoderma harzianum. Journal of Natural Products 54: 396-402 (1991).

17) Rifai M. A. Revision of Genus Trichoderma. Mycological Papers 116: 1-56 (1969).

18) Papavizas G. C. Trichoderma and Gliocladium Biology, Ecology and Potential for Biocontrol. Annual Reviews of Phytopathology 23: 23-54 (1985).

19) Dunlop R. W., Simon A., and Sivasithamparam K. An Antibiotic from Trichoderma koningii Active Against Soilborne Plant Pathogens. Journal of Natural Products 52: 67-74 (1989).

20) Ghisalberti E. L., and Sivasithamparam K. Antifungal Antibiotics Produced by Trichoderma spp. Soil Biology and Biochemistry 23:1011-1020 (19

21) Ridout C. J., Coley-Smith J. R., and Lynch J. M. Enzyme activity and electrophoretic profile of extracellular protein induced in Trichoderma spp. by cell walls of Rhizoctonia solani. Journal of General Microbiology 132: 2345-2352 (1986).

22) Wilhite S. E., Lumsden R. D., and Straney D. C. Mutational analysis of gliotoxin production by the biocontrol fungus Gliocladium virens in relation to suppression of Pythium damping-off. Phytopathology 84:816-821(1994).

23) Cotes A., Thonart P., and Lepoivre P. Relationship between the protective activities of several strains of Trichoderma against dampingoff agents and their ability to produce hydrolytic enzyme activities in soil or in synthetic media. Med. Fac. Landbouww. Univ. Gent. 59:931-941(1994).

24) Benhamou N., Lafontaine P. J., and Nicole M. Induction of systemic resistance to Fusarium crown and root rot in tomato plants by seed treatment with chitosan. Phytopathology 84:1432-1444(1994). 
25) Carsolio C., Gutiérrez A., Jiménez B., van Montagu M., and Herrera-Estrella A. Characterization of ech-42, a Trichoderma harzianum endochitinase gene expressed during mycoparasitism. Proc. Natl. Acad. Sci. U.S.A. 91:10903-10907(1994).

26) Lorito M., Peterbauerg C., Hayes C. K., and Harman G. E. Synergistic interaction between fungal cell wall degrading enzymes and different antifungal compounds enhances inhibition of spore germination. Microbiology 140:623-629(1994).

27) Goldman G. H., Hayes C., and Harman G. E. Molecular and cellular biology of biocontrol by Trichoderma harzianum. Trends in Biotechnology 12:478-482 (1994).

28) Laduvoca I., and Gogorova L. Biological control of phytopathogenic fungi through lytic action of Trichoderma species. FEMS (Fed.Eur. Microbiol. Soc.) Microbiology Letters 52:193-198(1988).

29) Howell C. R., and Stipanovic R. D. Glioviridin, a new antibiotic from Gliocladium virens and its role in the biological control of Pythium ultimun. Candian Journal of Microbiology 29:321-324 (1983).

30) Howell C. R., and Stipanovic R. D. Mechanisms in the biocontrol of Rhizoctonia solani-induced cotton seedling disease by Gliocladium virens: Antibiosis. Phytopathology 85:469-472(1995).

31) Eziashi E. I., Omamor B., and Odigie E. E. Antagonism of Trichoderma viride and effects of extracted water soluble compounds from Trichoderma species and benlate solution on Ceratocystis paradoxa. African Journal of Biotechnology. 6(4), pp.388-392, (2007).

32) Safdi N., Cherif M., Hajlaoui M. R., Boudabbous A., and Belanger R. Isolation and partial purification of antifungal metabolites produced by Bacillus cereus. Annual Microbiology. 52:323-337 (2002).

33) Gupta C. P., Dubey R. C., Kang S. C., and Maheshwari D. K. Antibiosis-mediated necrotrophic effect of Pseudomonas GRC2 against two fungal plant pathogens. Current Science. 81(1): 91-94 (2001).

34) Marfori E. C., Kajiyama S., Fukusaki E., and Kobayashi A. Trichsetin, anovel tetramic acid antibiotic produced in dual culture of Trichoderma harzianum and Catharanthus roseus callus Z.Naturforsch. 57c: 465-470 (2002).

35) Kucuk C., and Kivanc M. In Vitro antifungal activity of strains of Trichoderma harzianum. Turkish Journal of Biology 28: 111- 115 (2004). 